\title{
Gel Formation of Soybean 7S and 11S Proteins
}

\author{
Kazuko Shimada and Setsuro Matsushita \\ Research Institute for Food Science, Kyoto University, Kyoto, Japan \\ Received October 15, 1979
}

\begin{abstract}
Rheological properties of soybean $7 \mathrm{~S}$ and $11 \mathrm{~S}$ proteins were investigated at the concentrations in which both could form the heat-induced gel. It was recognized that $7 \mathrm{~S}$ protein formed gel at the lower concentration than that of 11S protein. In forming gel, 11S protein seems to have the ability to form more hydrogen bonds and ionic attractions and less hydrophobic interactions than those of $7 \mathrm{~S}$ protein. In the presence of salts, the gel of $7 \mathrm{~S}$ protein was formed at the lower protein concentration compared with the absence of salts. But the addition of salts to 11S protein suppressed the formation of gel even with high protein concentration. The reactivity of carboxyl groups was determined by the dye-binding method. The $11 \mathrm{~S}$ protein contained reactive carboxyl groups.
\end{abstract}

Soybean proteins possess excellent functional properties for food applications, and its protein concentrate and isolate are largely utilized in food processing and manufacturing.

It has been known that the main storage proteins in soybean, 7S and $11 \mathrm{~S}$ globulins differ in gelation behavior. The calcium-induced coagulum (Tofu-gel) and heat-induced gel formed from 11S globulin were firmer than those formed from $7 \mathrm{~S}$ globulin. ${ }^{1,2)}$ The 11S globulin fraction formed the heat-induced gel with high water-holding property compared with the 7S globulin. ${ }^{3}$ The differences of functional properties between $7 \mathrm{~S}$ and $11 \mathrm{~S}$ globulins are interesting problems to be solved.

Rheological properties of soybean protein dispersions were influenced by several factors: shear rates, protein concentration, heat treatment, $\mathrm{pH}$ and ionic strength. ${ }^{4,5)}$ Catsimpoolas and Meyer $^{6)}$ showed that the slurry of soybean globulins (the sol) was activated by heating to a progel state which is characterized by a marked increase in apparent viscosity and a reversible gel(an additional increase in apparent viscosity) was obtained by cooling the progel.

In this paper, rheological properties of $7 \mathrm{~S}$ and $11 \mathrm{~S}$ globulins are shown in order to speculate the occurrence of protein-protein interactions on gelation, and the difference of heatinduced gels between both fractions are compared.

\section{MATERIALS AND METHODS}

Preparation of crude 75 and $11 S$ globulin fractions. The soybean meal defatted under low temperature was supplied from Honen Seiyu Co. Crude $7 \mathrm{~S}$ and $11 \mathrm{~S}$ globulin fractions were prepared by the method of Thanh and Shibasaki. ${ }^{7)}$ Both fractions were dialyzed against distilled water and lyophylized. These crude $11 \mathrm{~S}$ and $7 \mathrm{~S}$ fractions contained about $95 \%$ of $11 \mathrm{~S}$ globulin and $80 \%$ of $7 \mathrm{~S}$ globulin, respectively, detecting by ultracentrifugal analysis.

Viscosity measurement. The viscosities of protein dispersions were measured by a Haake Rotovisco model RV 11 using a sensor system NV. Protein dispersions were adjusted to $\mathrm{pH} 7.5$ or 9.0 with $1 \mathrm{~N} \mathrm{NaOH}$. Protein solution was heated at $80^{\circ} \mathrm{C}$ for 30 min directly in the viscometer with rotating at shear rate, $175.2 \mathrm{~s}^{-1}$. After a shear stress was determined at shear rate, $525.7 \mathrm{~s}^{-1}$, the rotor was immediately cooled, maintained as $25^{\circ} \mathrm{C}$ for $10 \mathrm{~min}$ while again rotating at $175.2 \mathrm{~s}^{-1}$ and a shear stress was measured at shear rate, $525.7 \mathrm{~s}^{-1}$. Protein concentration was determined by drying samples to constant weight at $110^{\circ} \mathrm{C}$.

Texturometer measurement. The textural properties of gel were determined by a Texturometer (General Food Co. GXT-2). The clearance between plunger and plate was adjusted to $2 \mathrm{~mm}$. Hardness was measured from the profile of the first chew using a visco type plunger and a cup of $24 \mathrm{~mm}$ diameter. After the cup was heated at $80^{\circ} \mathrm{C}$ for $30 \mathrm{~min}$, cooled and stood at $4^{\circ} \mathrm{C}$ for $1 \mathrm{hr}$. Hardness of the formed gel was determined at room temperature.

Dye-binding method. Dye-binding method was performed by the procedure of Fraenkel-Conrat and Cooper. $^{8)}$ Protein solution was dissolved in $M / 15$ 
$\mathrm{KH}_{2} \mathrm{PO}_{4}-\mathrm{Na}_{2} \mathrm{HPO}_{4}$ buffer ( $\mathrm{pH}$ 7.5). The protein concentrations of $7 \mathrm{~S}$ and 11S proteins determined by the Biuret method ${ }^{\text {})}$ were $4.7 \mathrm{mg} / \mathrm{ml}$ and $5.0 \mathrm{mg} / \mathrm{ml}$, respectively. A $2 \mathrm{ml}$ of safranin $O$ (Chroma-Gesellschaft, Germany) solution in water was added in a $0.5 \mathrm{ml}$ of protein solution and the sample solution was shaken at $30^{\circ} \mathrm{C}$ for $30 \mathrm{~min}$ and then centrifuged. The supernatant solution was diluted, and the optical density was read at $520 \mathrm{~nm}$. The optical densities were the same though the shaking period were varied from $5 \mathrm{~min}$ to $18 \mathrm{hr}$. The dyes bound to the protein were determined by subtracting the amount left in the supernatant from the amount added.

\section{RESULTS}

\section{Viscosity measurement}

Since the heat-denaturated protein solutions showed thixotropic properties, the viscosity data were shown as the "apparent viscosity" at shear rate, $525.7 \mathrm{~s}^{-1}$. Figure 1 showed the effect of protein concentration and temperature on the viscosity at $\mathrm{pH} 7.5$ for the $7 \mathrm{~S}$ and $11 \mathrm{~S}$ proteins. The apparent viscosity of the 7S protein increased from the lower protein concentration at each 80 and $25^{\circ} \mathrm{C}$ than that of the $11 \mathrm{~S}$ protein. For both fraction, the ap-

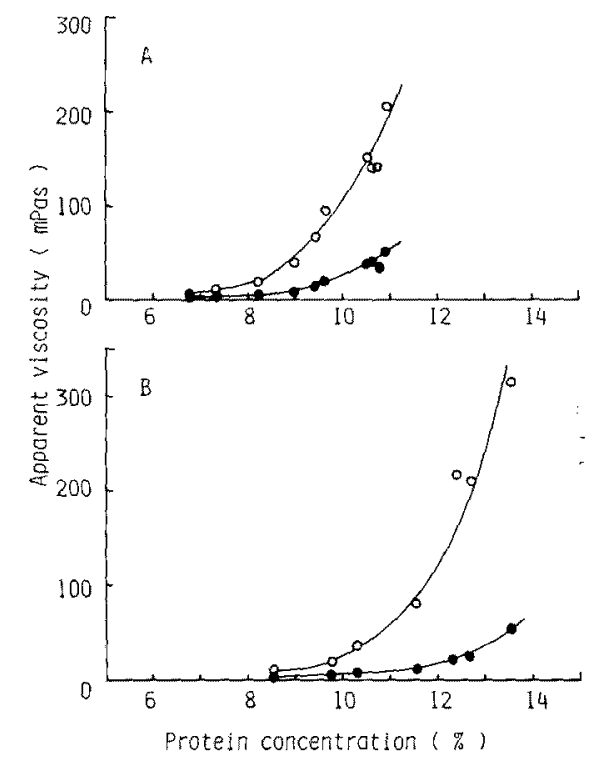

FIG. 1. Effect of Protein Concentration and Temperature on Apparent Viscosity at pH 7.5.

Apparent viscosities were measured at $80^{\circ} \mathrm{C}$ and $25^{\circ} \mathrm{C}(\mathrm{O}-\mathrm{O})$ as described in Methods. A: 7S protein. B: 11 S protein. parent viscosity at $\mathrm{pH} 9.0$ increased from the lower protein concentration than that at $\mathrm{pH}$ 7.5 (Fig. 2).

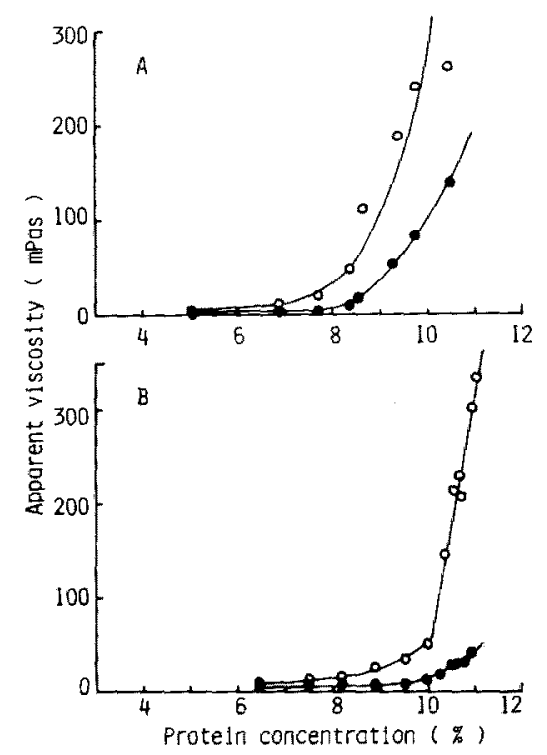

Fig. 2. Effect of Protein Concentration and Temperature on Apparent Viscosity at pH 9.0.

Apparent viscosities were measured at $80^{\circ} \mathrm{C}$ and $25^{\circ} \mathrm{C}(\mathrm{O}-\mathrm{O})$ as described in MeThods. A: $7 \mathrm{~S}$ protein. B: 11S protein.

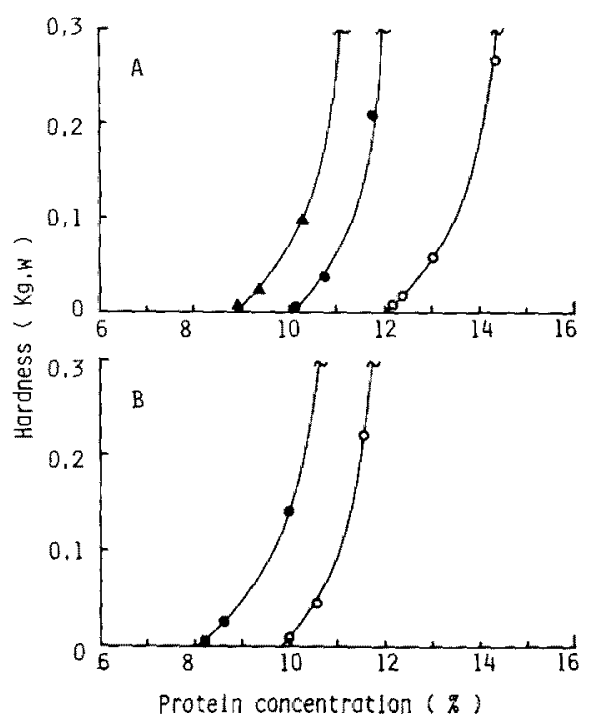

Fig. 3. Effect of $\mathrm{pH}$ on the Formation of Heatinduced Gel for $7 \mathrm{~S}$ and $11 \mathrm{~S}$ Proteins.

$(\bullet)$, 7S protein; $(0-0)$, $11 \mathrm{~S}$ protein; $(\mathbf{\Delta}-\mathbf{\Delta})$, $7 \mathrm{~S}$ protein added $0.3 \mathrm{M}$ sodium chloride. $\mathrm{A}: \mathrm{pH} 7.5$. B: $\mathrm{pH} 9.0$. 


\section{Formation of heat-induced gel}

Figure 3 shows the formation of gel from the $7 \mathrm{~S}$ and $11 \mathrm{~S}$ proteins at each $\mathrm{pH} 7.5$ and 9.0. The minimum protein concentrations of the $7 \mathrm{~S}$ protein to form gel was lower than those of the

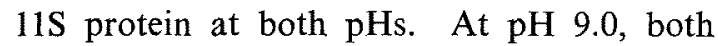
protein fractions formed gel at the lower protein concentrations than those at $\mathrm{pH} 7.5$. These tendencies were also the same with those of viscosities.

\section{Effect of ionic strength}

The 7S and 11S dispersions ( $\mathrm{pH} 7.5$ ) containing $0.3 \mathrm{M}$ sodium chloride were heated at $80^{\circ} \mathrm{C}$ for $30 \mathrm{~min}$ and then cooled down to $25^{\circ} \mathrm{C}$. The apparent viscosity at 80 and $25^{\circ} \mathrm{C}$ were measured (Fig. 4). The apparent viscosity of the $7 \mathrm{~S}$ protein in the presence of sodium chloride began to increase at the lower protein concentration than that in the absence of salts. The measurement by the texturometer showed that the $7 \mathrm{~S}$ protein containing $0.3 \mathrm{M}$ sodium chloride began to form gel at the lower protein concentration than that without salts (Fig. 3). On the other hand, the addition of $0.3 \mathrm{M}$

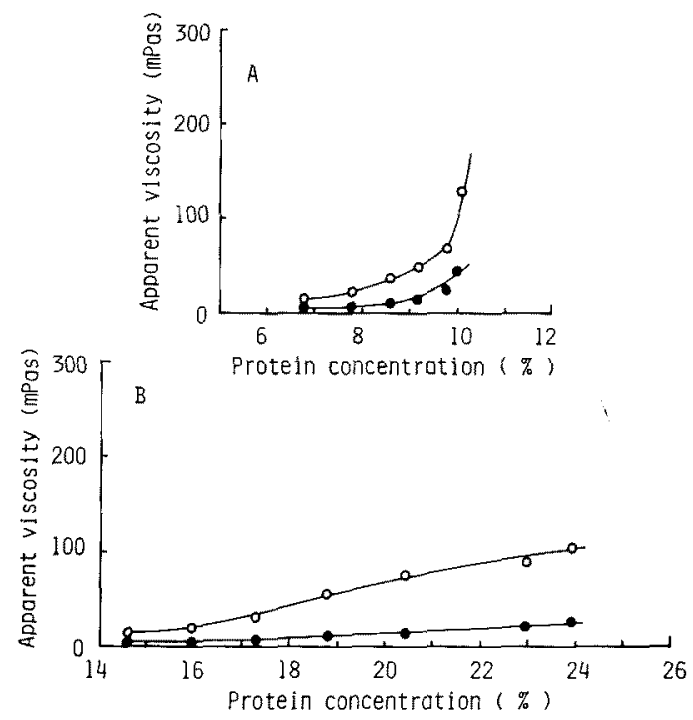

FIG. 4. Effect of $0.3 \mathrm{M}$ Sodium Chloride on the Apparent Viscosity at $\mathrm{pH} 7.5$.

Apparent viscosities were measured at $80^{\circ} \mathrm{C}(-\bullet)$ and $25^{\circ} \mathrm{C}(\mathrm{O}-\mathrm{O})$ as described in Mertrods. A: $7 \mathrm{~S}$ protein. B: $11 \mathrm{~S}$ protein. sodium chloride to $11 \mathrm{~S}$ protein inhibited the increase of viscosity even at higher protein concentrations. Within the protein concentrations used in this experiment, the $11 \mathrm{~S}$ protein did not form gel by the addition of salts.

\section{Dye-binding measurement}

The difference of dye-binding ability between $7 \mathrm{~S}$ and $11 \mathrm{~S}$ proteins was investigated by using a basic dye, safranin $O$ (Fig. 5). The $11 \mathrm{~S}$ protein bound more safranin $O$ than the $7 \mathrm{~S}$ protein at the dye concentrations below $6 \times$ $10^{-4} \mathrm{~mol} / \mathrm{l}$. But, at the condition of dye concentration above $6 \times 10^{-4} \mathrm{~mol} / 1$, the $7 \mathrm{~S}$ protein bound more dyes than the $11 \mathrm{~S}$ protein. The amount of the precipitated proteins was determined by drying at $110^{\circ} \mathrm{C}$. When the half of each $7 \mathrm{~S}$ and $11 \mathrm{~S}$ proteins was precipitated, the dye concentrations were about $4.7 x$ $10^{-4} \mathrm{~mol} / \mathrm{l}$ and $2.7 \times 10^{-4} \mathrm{~mol} / 1$, respectively. (not shown here). Both $7 \mathrm{~S}$ and $11 \mathrm{~S}$ proteins that were previously heat-denaturated at $80^{\circ} \mathrm{C}$ for $30 \mathrm{~min}$ showed the dye-binding abilities as well as those of the native proteins.

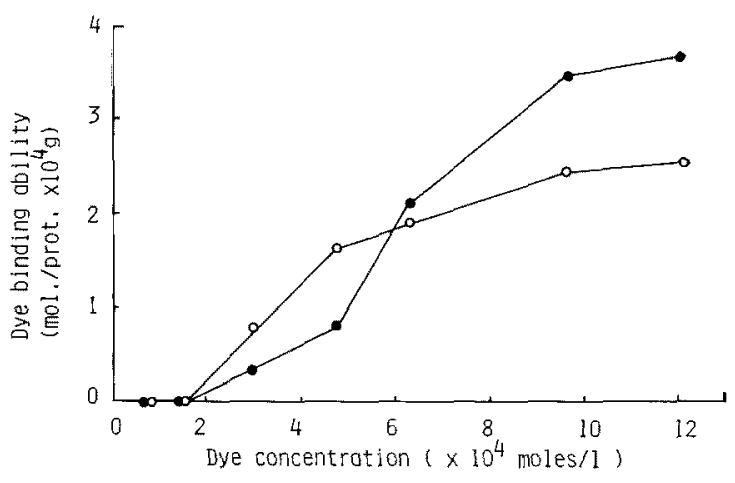

FIG. 5. Dye-binding Ability of $7 \mathrm{~S}$ and $11 \mathrm{~S}$ Proteins.

(-), $7 \mathrm{~S}$ protein, $(\mathrm{O}-\mathrm{O}), 11 \mathrm{~S}$ protein.

\section{DISCUSSION}

The minimum protein concentration to form gel differs among each protein. It is considered to be due to the difference of molecular weight (including formation of disulfide bond), net charge, amino acid composition, etc. In this experiment, the $7 \mathrm{~S}$ protein formed gel at the lower protein concentration than the $11 \mathrm{~S}$ 
protein (Fig. 3). In the process of gelation, a three-dimensional network is formed throughout the material. The formation of gel requires the cross-links among protein molecules. ${ }^{10)}$ The rigidity of gel (force per unit area) seems to reflect the product of number and intensity of the protein-protein interactions. On the other hand, since the viscosity was always measured in the rotating state, it seems likely that the intensity of cross-links among protein molecules detected by viscometer is weaker than that of stationary state. However, the viscosity may indicate roughly the number of the cross-links among protein molecules. The relative amount of the protein-protein interactions seems to be compared roughly from the data of viscosity measurement on each protein concentration in which the gel from the $7 \mathrm{~S}$ and $11 \mathrm{~S}$ proteins are the same hardness. The apparent viscosities were compared at the protein concentrations in which the hardness of gel from the $7 \mathrm{~S}$ and $11 \mathrm{~S}$ proteins was 0.75 (Fig. 6). The 7S protein showed higher viscosity than the $11 \mathrm{~S}$ protein at $80^{\circ} \mathrm{C}$, but with respect to the change of viscosity accompanied

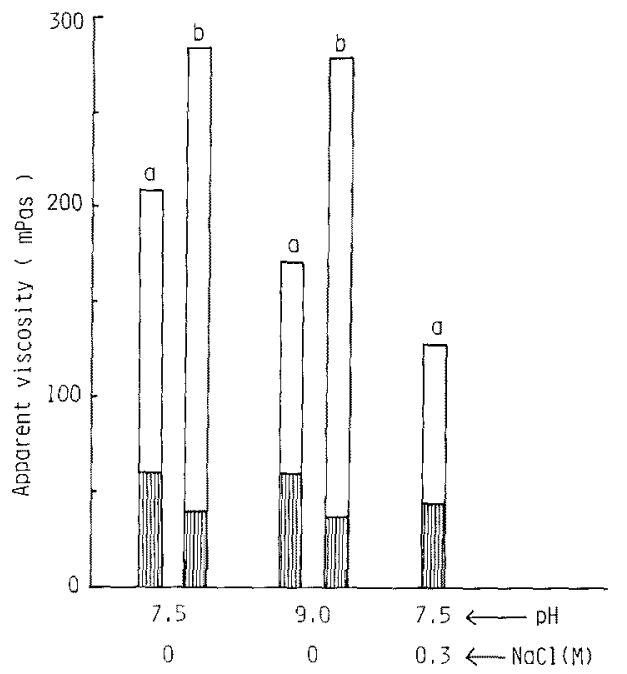

FIG. 6. Comparison on the Apparent Viscosities at 80 and $25^{\circ} \mathrm{C}$ for $7 \mathrm{~S}$ and $11 \mathrm{~S}$ Proteins.

The viscosities at the protein concentration in which the hardness of gel was 0.75 were compared. (a), $7 \mathrm{~S}$ protein; (b), 11S protein. ( sity at $80^{\circ} \mathrm{C}$; $\square$ ), increase of the apparent viscosity by the fall of temperature from $80^{\circ} \mathrm{C}$ to $25^{\circ} \mathrm{C}$. by the fall of temperature from 80 to $25^{\circ} \mathrm{C}$, the $11 \mathrm{~S}$ protein showed more increase of viscosity than the $7 \mathrm{~S}$ protein. Hydrophobic interaction is favored by a rise in temperature, ${ }^{117}$ while at lower temperatures hydrogen bond and ionic interactions are favorable. From the data of this experiment, it seems likely that the protein-protein interactions of the $7 \mathrm{~S}$ protein involved relatively much hydrophobic interactions, while the interactions of the $11 \mathrm{~S}$ protein involved many hydrogen bond and ionic interactions. The viscosity at $\mathrm{pH} 9.0$ showed the similar tendency to the viscosity at $\mathrm{pH} 7.5$ (Fig. 6).

Effect of salts to proteins is largely complicated. It has been reported that salts rupture ionic attraction on proteins, affect hydrogen bond and indirectly enhance hydrophobic interaction. ${ }^{2)}$ By adding $0.3 \mathrm{M}$ sodium chloride, the minimum protein concentration to form gel of the $7 \mathrm{~S}$ protein shifted to the lower concentration than that of without salts (Fig. 3). The viscosity at $80^{\circ} \mathrm{C}$ on the protein concentration in which the hardness of gel was 0.75 showed the lower value than that of without salts (Fig. 6). As the increase of viscosity accompanied by the fall of temperature from 80 to $25^{\circ} \mathrm{C}$ was not so much, the hydrophobic interaction at higher temperature may greatly participate in the rigidity of the gel. The viscosity of the $11 \mathrm{~S}$ protein dispersion containing salts did not increase even at the high protein concentration and the gel was not formed at the protein concentration used in this experiments (Fig. 4). It is deduced that, because of some carboxyl groups forming strongly ionic attraction with salts and inhibiting intra- and interaction of proteins, the contacts among proteins become difficult.

Safranin $O$ is generally used for the determination of acidic amino acids, ${ }^{9,13}$ and the dye solution has normally been chosen at the high concentration of about $5 \times 10^{-3} \mathrm{~mol} / \mathrm{l}$, but in order to compare the reactivity of carboxyl groups, the lower dye concentration was used in this experiment. In the condition of lower dye concentration, the $11 \mathrm{~S}$ protein bound more dyes than the $7 \mathrm{~S}$ protein (Fig. 5). The 
dye-binding amounts of heat-denaturated protein was the same as the native protein. Therefore, the difference between the $7 \mathrm{~S}$ and $11 \mathrm{~S}$ proteins for dye-binding ability may be due to that of the reactivity of carboxyl groups itself rather than that of their conformations. The amino acid sequence near carboxyl groups in $11 \mathrm{~S}$ protein may have some specific structure such as the carboxyl groups are able to have higher reactivity. On the condition of higher dye concentration, the $7 \mathrm{~S}$ protein bound more dyes than the $11 \mathrm{~S}$ protein. Many investigators have reported that the $11 \mathrm{~S}$ globulin contains much amide forms. ${ }^{14 \sim 17}$, Consequently, it may explain the much dye-binding ability of the $7 \mathrm{~S}$ protein at higher dye concentration. The presence of the reactive carboxyl groups in the $11 \mathrm{~S}$ protein may be correlated with the facts that the addition of salts suppressed the formation of gel of the $11 \mathrm{~S}$ protein at this experiment, the $11 \mathrm{~S}$ protein was easily precipitated by calcium salts ${ }^{2)}$ and the calciuminduced or heat-induced gels of the 11S protein were rigider than that of the $7 \mathrm{~S}$ protein. ${ }^{1,2)}$

Acknowledgment. The authors are indebted to Dr. Daizo Yonezawa, Research Institute for Food Science, Kyoto University, for his valuable discussions.

\section{REFERENCES}

1) K. Saio, M. Kamiya and T. Watanabe, Agric. Biol. Chem., 33, 1301 (1969).

2) K. Saio, T. Watanabe and M. Kaji, J. Food. Sci., 38, 1139 (1973).

3) K. Saio, I. Sato and T. Watanabe, Nippon Shokuhin Kogyo Gakkaishi, 21, 234 (1974).

4) S. J. Circle, E. W. Meyer and R. W. Whitney, Cereal Chem., 41, 157 (1964).

5) J. Ehninger and D. Pratt, J. Food Sci., 39, 892 (1974).

6) N. Catsimpoolas and E. W. Meyer, Cereal Chem., 47, 559 (1970).

7) V. H. Thanh and K. Shibasaki, J. Agric. Food Chem., 24, 1117 (1976).

8) H. Fraenkel-Conrat and M. Cooper, J. Biol. Chem., 154, 239 (1944).

9) A. G. Gornall, C. S. Bardawill and M. M. David, ibid., 177, 751 (1949).

10) J. D. Ferry, Adv. Protein Chem., 4, 1 (1948).

11) G. Némethy, I. Z. Steinberg and H. A. Scheraga, Biopolymers, 1, 43 (1963).

12) P. K. Nandi and D. R. Robinson, J. Amer. Chem. Soc., 94, 1308 (1972).

13) R. Hamm and F. E. Deatherage, Food Res., 25, 587 (1960).

14) D. Fukushima, Cereal Chem., 45, 203 (1968).

15) I. Koshiyama, ibid., 45, 394 (1968).

16) K. Saio, M. Terashima and T. Watanabe, $J$. Food Sci., 40, 541 (1975).

17) R. A. Badley, D. Atkinson, H. Hauser, D. Oldani, J. P. Green and J. M. Stubbs, Biochim. Biophys. Acta, 412, 214 (1975). 